\title{
VERB MOVEMENT AND INTERROGATIVES
}

\section{Introduction}

Verb movement is a phenomenon that has been studied extensively within the framework of Chomskyan generative grammar. The pioneering work by Pollock (1989) has been followed by a number of studies involving various languages, which has provided an important insight both into the language-specific and language-universal properties of verb movement. In most general terms, verb movement can be defined as movement of the verb from its base position in the (V)erb (P)hrase to some position higher in the clausal structure. In Government \& Binding theory verb movement was motivated by the need of the bare lexical verb to associate with the inflectional affixes hosted by the functional heads (Pollock 1989, Belletti 1990). By contrast, the Minimalist Program (Chomsky 1995) claims that all types of movement are triggered by feature-checking requirements. In this system, items from lexical categories are fully inflected in the lexicon. Thus the verb is inserted into its base position with all its inflectional affixes and associated inflectional features. Functional heads do not contain any inflectional material; they carry only abstract features, which are checked against the corresponding features on the lexical items. In order for feature-checking to take place the lexical item (e.g. the verb) must raise to the relevant functional head(s).

This paper is an attempt at a syntactic account of the type of verb movement displayed in interrogative clauses containing a wh-element. In the generative literature, this type of movement, standardly known as 'I-to-C movement', has been related to the Wh-Criterion (Rizzi 1991). It has been claimed that the inflected verb must raise from I(nflection) to C(omplementizer) so as to be in a Spec(ifier)-head configuration with the wh-element in the specifier of the $\mathrm{C}$ (omplementizer) $\mathrm{P}$ (hrase). In this paper, verb movement in wh-interrogatives ${ }^{1}$ in English, French and Slovenian will be examined from a comparative perspective, with special attention being paid to the following issues: (i) what are the general properties of verb movement in wh-interrogatives; (ii) how can this type of movement be analysed by adopting the basic concepts and tenets of the Minimalist Program (Chomsky 1995); and (iii) to what extent do the empirical observations follow from the general principles of the Minimalist Program.

The paper is organised as follows. Section 1 provides a brief outline of the Minimalist theoretical framework adopted in this examination. Section 2 deals with verb

1 The discussion will be restricted to constituent questions; echo questions will not be considered. 
movement in English and French interrogatives with special emphasis on the familiar of root/embedded asymmetry of I-to-C movement. In section 3 we focus on interrogative I-to-C in Slovenian and propose an analysis of I-to-C movement in terms of a modified Minimalist checking theory of movement which provides a uniform account of different properties of interrogative I-to-C in languages of the English/French, Spanish and Slovenian type. In Section 4 we offer our conclusions on the research.

\section{Theoretical background}

\subsection{The Minimalist Program: basic concepts and assumptions}

Minimalism is an attempt to reduce the theory of grammar to the essential three components any theory of grammar ${ }^{2}$ must have: a lexicon, an interface with the articulatory-perceptual system and an interface with the semantic-conceptual system. The Minimalist Program thus postulates only two levels of structural representation, the interface levels of Phonetic Form (PF) and Logical Form (LF) ${ }^{3}$, a lexicon and a computational system which builds structures that constitute PF and LF representations. The Minimalist model is shown in (1).

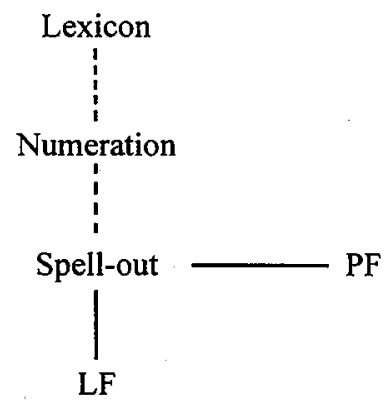

The structure-building process starts with Numeration - a set of lexical items from which a structure is to be formed. The computational system builds up structures in a step-by-step fashion, by selecting elements from the Numeration (the operation Select), combining the selected elements and partially formed structures (the operation Merge), and by moving elements that are already part of the structure (the operation Move). The computational system is constrained by economy conditions requiring that derivations be as economical as possible. ${ }^{4}$ At some point in the computation (Spell-Out), the derivation splits and heads toward the two interface levels. At Spell-Out phoneti-

2 A 'theory of grammar' in the Chomskyan sense, i.e. a theory of linguistic competence.

3 "This 'double interface' property is one way to express the traditional description of language as sound with a meaning [...]" (Chomsky 1995: 2).

4 "[...] derivations and representations conform to an "economy" criterion demanding that they be minimal: no extra steps in derivation, no extra symbols in representation, etc" (Lasnik 1999: 26). 
cally relevant information is separated from semantically relevant information, so that ultimately two independent representations are formed: PF representation, containing phonetic information and an LF representation, containing semantic information.

A lexical item is defined as a set of phonological, semantic, and formal features. Formal features (e.g. tense and agreement features) occur both in lexical and functional categories. Since formal features are relevant only to the computational system and play no role at the PF and LF interfaces, they must be eliminated in the course of the derivation. This is achieved by feature-checking - a matching of the features, which in effect cancels them out. This matching is brought about by the operation Move. For instance, in order for tense and agreement features to be checked, the verb has to raise and adjoin to the functional categories $\mathrm{T}$ (ense) and Agr(eement).

Features of the functional categories can be either strong or weak. Strong features are visible at PF and therefore have to be checked off before Spell-Out. If strong features are spelt out, the derivation crashes. Weak features, on the other hand, are invisible at PF and may therefore be checked after Spell-Out. Accordingly, there are two types of movement: overt (pre-Spell-Out) and covert (LF) movement. Movement is subject to the economy principle Procrastinate, which requires that it be delayed until after Spell-Out as long as this does not cause the derivation to crash. Overt movement thus occurs only when it has to (the principle of Last Resort), that is, in the presence of a strong feature.

\subsection{Clause structure}

According to the $\mathrm{X}$-bar theory of phrase structure ${ }^{5}$ the basic clause structure is as shown in (2a). A clause is a maximal projection IP headed by the functional category I. The specifier of IP is the subject of IP and the VP is the complement of I. The type of clause (i.e. declarative, interrogative, imperative) is determined by the functional category C(omplementizer), which takes IP as its complement, so that a full clause has the structure $(2 b)$.
a) [IP Spec [r, I VP]]
b) $\left[\mathrm{CP}\right.$ Spec $[\mathrm{C}, \mathrm{C}[\mathrm{rP} \text { Spec [r, I VP] }]]^{6}$

\section{Wh-movement and Verb movement - English and French}

Wh-movement is involved in the formation of interrogative sentences where a whphrase raises from its base position to the specifier of $\mathrm{CP}$ [Spec, CP]. Wh-phrases have operator-like properties and wh-structures are subject to the Wh-Criterion (3a), requiring configurations as in (3b).

5 Since the 1970s X-bar theory has been standardly assumed in Chomskyan grammar, including early work on Minimalism (cf. Chomsky 1995, chapters 1-3). More recently, however, Chomsky has proposed to eliminate the $\mathrm{X}$-bar as a separate module of the grammar, arguing that restrictions on the form of structural descriptions follow directly from the properties of structure-building processes themselves (cf. op.cit.: chapter 4).

$6 \mathrm{CP}=$ Complementizer Phrase; $\mathrm{IP}=$ Inflectional Phrase; $\mathrm{VP}=$ Verb Phrase, $\mathrm{Spec}=$ specifier. 
(3) a) The Wh-Criterion

A. A Wh-Operator must be in a Spec-head configuration with an $\mathrm{X}_{[++\mathrm{WH}]}^{\mathrm{o}}$.

B. An $\mathrm{X}_{[+\mathrm{WH}]}^{\mathrm{O}}$ must be in a Spec-head configuration with a Wh-operator.

b)

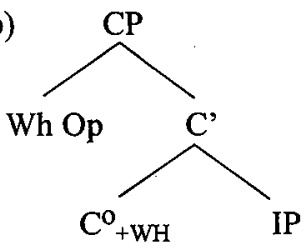

Rizzi (1991: 2, (6))

As a general well formedness condition on the scope of wh-operators, the WhCriterion applies universally at LF, but some languages may require it to be satisfied earlier. Under Minimalist assumptions, in languages with a strong [+wh] feature (English (4a), French (4b, $\left.\mathrm{b}^{\prime}\right)$ ), the movement of the wh-phrase will occur already in the overt syntax (i.e. before Spell-Out), whereas in languages with a weak [+wh] feature, the condition is met at LF, by covert wh-movement (Japanese $-(4 c)$ ).

(4) a) Where did she go?

b) Que veux-tu?

what want-you

b') Qu' est-ce que tu veux? what $\mathrm{Q}^{7} \quad$ you want

'What do you want?'

c) John-ga doko-ni ikimasa (ka)

John where gone-has - $k$

'Where has John gone?'

In sentences with overt wh-movement (4a-b'), the wh-phrase is separated from the subject by a phonologically overt element, which can be a finite verbal form $(4 a, b)$, or a question particle $\left(4 b^{\prime}\right)$.

In the sections that follow, we will try to establish what licenses subject-finite verb inversion (Subj-Vfin) in $(4 a, b)$ as well as the presence of the question particle in $\left(4 b^{\prime}\right)$.

\subsection{Data I}

\subsubsection{ENGLISH}

In English, subject/finite verb inversion occurs in root interrogatives with the raised wh-phrase in [Spec, CP], unless the wh-phrase functions as subject (cf. (5a,b)). The inverted order is standardly assumed to be derived by the finite verb raising from its position in I to the position $\mathrm{C}$. This movement is restricted to auxiliaries; main verbs

7 Q denotes the question particle. 
do not move (5c). In embedded interrogatives, verb movement, resulting in the inverted order is not allowed (5d).

(5) a) What have you done?

b) Who has done it?

c) *What want you?

d) I wonder what * $\{$ have $\}$ you $\{$ have $\}$ done.

\subsubsection{FRENCH}

There are three different ways of forming interrogatives in French:

(i) wh-phrase in situ (wh-movement applying covertly) (6a);

(ii) wh-phrase overtly moved to [Spec, CP], C filled with the question particle estce que (6b);

(iii) wh-phrase overtly moved to [Spec, CP], C filled with the finite verbal form (6c).

As in the case of English, there is an asymmetry between root and embedded clauses. In the latter, wh-element in situ, verb movement to $\mathrm{C}$, and est-ce que in $\mathrm{C}$ are not possible (cf. 6d-f).

(6) a) $\mathrm{Tu}$ as vu qui? you have seen who

b) Qui est-ce que tu as vu? who $Q \quad$ you have seen

c) Qui as-tu vu? who have you seen

'Who have you seen?'

d) Je ne sais pas qui elle a vu $*$ qui\}.

I ne know not who she has seen

e) Je ne sais pas qui * $\{a\}$ elle a vu.

I ne know not who she has seen

f) Je ne sais pas qui * (est-ce que $\}$ elle a vu.

I ne know not who

she has seen

'I do not know who she has seen.'

\subsection{Asymmetric I-to-C movement}

As evidenced by the data in the previous section, both English and French root interrogatives with overt wh-movement require the presence of a phonologically overt element in C. This element can be either a finite verbal form (English, French) or a special interrogative particle (French). In the case of the former, the requirement is met by the verb raising to $C$. This movement involves only those verbal forms that are within the IP-domain; it does not affect VP-internal verbal elements. Following standard terminology, we will refer to this type of verb movement as I-to-C movement. 
Both languages exhibit a root/embedded asymmetry of I-to-C movement: it occurs in root interrogatives but is absent from embedded interrogatives. Given the Wh-Criterion (3), the root/embedded asymmetry is unexpected. If I-to-C movement must apply to establish a Spec-head configuration involving the wh-element and the inflected verb (Rizzi 1991: 1), why does it apply only in root and not also in embedded questions?

Rizzi (1991: 3-4) argues that in the case of embedded questions, the matrix verb (e.g. wonder in (5d)) selects an indirect question, hence a $\mathrm{CP}$ whose head $\mathrm{C}$ is marked by the feature $[+W H]$. Since the specification $[+W H]$ fills the embedded $\mathrm{C}$, the latter is not available as a landing site for I-to-C movement. Therefore the verb stays in I and there is no subject-finite verb inversion. The Wh-Criterion is satisfied by wh-movement, which creates the required Spec-head configuration (cf. (3b)).

Rizzi's account raises two questions.

(i) A filled $\mathrm{C}$ is claimed to prevent the verb from moving into it. However, the verb could raise and adjoin to $\mathrm{C}$. There is no apparent reason why adjunction to $\mathrm{C}$ should be excluded, hence a filled $\mathrm{C}$ as a motivation for the absence of verb movement is problematic.

(ii) Root questions involve two different types of movement: movement of an XP (wh-phrase) and head movement (I-to-C). Assuming the Minimalist checking theory of movement, the [+WH] feature of $\mathrm{C}$ induces wh-movement and is checked in the Spec-head configuration. The feature triggering I-to-C must be checked in a head-head configuration, but what is this feature?

In the next section we will address the question of trigger for I-to-C movement and the related issue of root/embedded asymmetry from the Minimalist perspective and propose an account of the asymmetry phenomenon based solely on the feature-checking requirements of the relevant functional head.

\section{3 [+QUESTION] feature as a marker of interrogative force}

As is well-known, differences in clause types are often mirrored in specific syntactic properties of individual clause types. For example, root declaratives in the majority of Germanic languages display the Verb-Second (V2) phenomenon (8a); root questions often require subject-verb inversion in SVO languages (8b); in directives the subject usually stays unexpressed even in non-pro-drop languages such as English (8c) ${ }^{8}$ :

a) Denne film har børnene set. Danish

(Rohrbacher 1999: 13, (2d)) this film have children seen

'The children have seen this film.'

b) Is she happy?

c) Go home.

8 For a discussion of these syntactic phenomena see Ilc (2002). 
Clause type is determined by the formal features hosted by the functional head C (Chomsky 1995), or, under the Split-CP Hypothesis, (Rizzi 1997), by the functional head Force of the highest projection in the CP-domain, the Force $\mathrm{P}(\text { hrase })^{9}$.

Adopting the assumption that $\mathrm{C}$ (Force) is the locus of clause-type features, we suggest that in the case of root interrogatives $\mathrm{C}$ (Force) contains the feature [+QUESTION]. This feature is a marker of the interrogative illocutionary force of the clause, and, as will be argued below, is not identical with the $[+w H]$ feature.

There are several pieces of empirical evidence that support the postulation of the [+QUESTION] feature:

(i) in the Chamorro language there is a special question verb paradigm (Chung 1982);10

(ii) the presence of question particles (est-ce que in French);

(iii) special question affixes (the suffix -ne in Latin ${ }^{11}$ ).

Based on the empirical evidence and the assumptions presented above, we propose that root interrogatives are clauses with the clausal head $\mathrm{C}$ (Force) containing the feature specification as in (9):

(9)

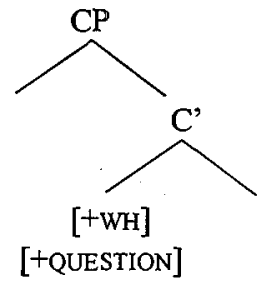

If both features in (9) are strong, they have to be checked in the overt syntax. The $[+w H]$ feature is checked in the Spec-head configuration, with the wh-element raising to [Spec, $\mathrm{CP}$ ]. The [+QUESTION] feature can be checked either by a lexical element carrying the corresponding feature: a verbal element (I-to-C movement) or a special question particle - cf. section 2.1 .

9 Under the Split-CP Hypothesis of Rizzi (1997), the formerly uniform CP-layer of projection is analysed as consisting of several distinct projections, ForceP $>$ Top(ic) $P>F o c(u s) P>F i n(i t e) P$.

10 The relevant examples:

a) Hay f-um-a'gasi i kareta? (Chung 1982: 49, (30a))

who ?-washed

the car

'Who washed the car?'

b) Ha-fa'gasi si Juan i kareta. (Chung 1982: 49, (30b)) washed case Juan the car

'Juan washed the car.'

11 The suffix -ne can attach to either verbal or non verbal elements. Consider:
a) Domine, dominae domine sunt?
b) Domine, dominae domi suntne?
Lord-voc ladies home are
'O lord, are the ladies at home?' 
Now let us consider two clause types which clearly show that [+WH] and [+QUESTION] are two distinct features, thus lending additional support to the proposed analysis.

\subsubsection{VERBAL QUESTIONS: NO [+WH] FEATURE}

Verbal questions $(10)$ have no wh-element, hence no [+wH] feature. They exhibit Ito-C movement, which is licensed by the presence of the [+QUESTION] feature. Since this feature is strong in French (10a) and in English (10b), I-to-C movement must apply overtly.

(10) a) Parlez-vous français? speak-you French

'Do you speak French?'

b) Has she arrived?

\subsubsection{EXCLAMATIVES: NO [+QUESTION] FEATURE}

English exclamatives are restricted to the type of exclamatory utterance introduced by what or how (Quirk et al., 1999: 833). These clauses are not interpreted as questions although they involve wh-movement to [Spec, $\mathrm{CP}$ ]. In languages with a strong [+wH] feature, such as English, wh-movement is overt (11a). The presence of the [+WH] feature in exclamatives, however, does not license I-to-C movement (cf. the ungrammaticality of (11b)). Exclamatives, being devoid of interrogative force, lack the [+QUESTION] feature, hence I-to-C is ruled out by the principle of Economy.

(11) a) What a time we have had today!

b) *What a time have we had today!

\subsubsection{ROOT/EMBEDDED ASYMMETRY REANALYSED}

As noted in section 2.2, Rizzi's (1991) account of the root/embedded asymmetry of I-to-C movement in interrogatives is problematic from the perspective of the Minimalist checking theory of movement. In particular, if the root $\mathrm{C}$ contains only the [+wH] feature, which triggers wh-movement, there is no feature to license I-to-C movement.

Our analysis of root interrogatives (9) provides a straightforward answer to the problem of trigger for I-to-C. The root $\mathrm{C}$ contains two features, $[+\mathrm{WH}]$ and [+QUESTION], the former licensing wh- movement and the latter I-to-C.

Now consider embedded interrogatives. The information about the illocutionary force of the clause is encoded in the highest functional projection in the CP-domain. In the case of embedding, this is the matrix CP; embedded clauses themselves have no illocutionary force, ${ }^{12}$ hence their $\mathrm{C}$ contains no illocutionary-force features. The

12 Cf. for instance sentences (i) and (ii): both contain embedded interrogatives, but neither has interrogative illocutionary force - (i) has declarative and (ii) exclamative force.

(i) I know what she said.

(ii) Tell me what she said. 
[+QUESTION] feature, being an illocutionary-force feature, is thus not present in the $\mathrm{C}$ of embedded interrogatives.

The root/embedded asymmetry can be fully accounted for in terms of presence/absence of the features [+WH] and [+QUESTION]. In root interrogatives, [+WH] triggers wh-movement to [Spec, $\mathrm{CP}]$ and [+QUESTION] triggers I-to-C movement. In embedded interrogatives, $[+\mathrm{WH}]$ triggers wh-movement to [Spec, $\mathrm{CP}]$, while I-to-C does not take place due to the absence of the [+QUESTION] feature.

To sum up, we have argued that the presence of the [+WH] feature licenses only one type of movement, namely the raising of a wh-element to [Spec, CP], where the [+WH] feature of $\mathrm{C}$ is checked against the corresponding feature of the raised wh-element. Ito- $\mathrm{C}$ movement is licensed by another feature on $\mathrm{C}$, the [+question] feature determining the interrogative force of a clause, which is present in the $\mathrm{C}$ of root interrogatives only. On this analysis, the root/embedded asymmetry is the result of different featural content of the clausal head $\mathrm{C}$, as shown in (12).

\begin{tabular}{|c|c|c|}
\hline $\mathrm{CP}_{\text {interrogative/root: }}$ & $\begin{array}{l}\text { Feature(s) of } \mathbf{C} \\
{[+ \text { WH }]} \\
{[+ \text { QUESTION }]}\end{array}$ & $\begin{array}{l}\text { Type of movement } \\
\text { wh-movement } \\
\text { I-to-C movement }\end{array}$ \\
\hline $\mathrm{CP}_{\text {interrogative/embedded: }}$ & {$[+w H]$} & wh-movement \\
\hline
\end{tabular}

\subsection{Subject - Finite Verb+Non-finite Verb inversion in French}

The analysis of interrogatives proposed in 2.3 above is based on the data involving only English interrogatives and those French interrogatives where the subject is weak. ${ }^{13}$ In this section we will take a look at French interrogatives containing a strong subject.

\subsubsection{DATA II}

In interrogatives containing a strong subject, both the finite and the non-finite verbal forms of composite tenses precede the strong subject, indicating the movement of the finite and non-finite verbal forms across the subject (Subj $-V_{\text {fin }}+V_{\text {non-fin }}$ inversion) - (13a). ${ }^{14}$ This type of inversion is obligatory, as witnessed by the ungrammaticality of (13b). In the case of a weak subject, Subj $-\mathrm{V}_{\text {fin }}+\mathrm{V}_{\text {non-fin }}$ inversion is not allowed (cf. the ungrammaticality of (14a)), only the finite verbal form can move (14b).

13 Weak subjects are realised by weak personal pronouns (as in French: je, tu, illelle, nous, vous, ils/elles), the null subject (pro) and expletives; strong subjects are realised by strong pronouns (as in French: moi, toi, luilelle, nous, vous, eux/elles) and $\mathrm{R}$ (eferential) expressions. As argued by Cardinaletti (1997), strong subjects can either precede or follow the finite verbal from, whereas weak subjects are restricted to pre-verbal position, cf. (i)

(i) $\{$ Jean/il $\}$ est parti $\left\{\right.$ Jean $/ *^{*}$ il $\} \quad$ (Cardinaletti 1997: 36; (7)) Jean/he is left Jean/he 'Jean has left.'

14 This type of inversion occurs also in Italian interrogatives (cf. Rizzi 1991) 
(13) a) Où a été Jean?

(Pollock 2001a: 4; (50d), (50c)) where has been Jean

b) *Où a Jean été? where has been Jean

'Where has Jean been?'

(14) a) *Quand va téléphoner il? when go phone he-weak

(Pollock 2001b: 1, (2d),(2a))

b) Quand va-t-il téléphoner ?

'When will he phone?'

In embedded interrogatives with a strong subject, $S u b j-V_{\text {fin }}+V_{\text {non-fin }}$ inversion may but need not apply (cf. (15a,b)). In embedded interrogatives with a weak subject (15c) neither Subj $-V_{\text {fin }}+V_{\text {non-fin }}$ inversion nor subject-finite verb inversion is possible (15d,e).

(15) Je ne sais pas

I ne know not

(Pollock 2001b: 1, (4))

'I don't know'

a) quand va téléphoner Yves. when goes phone Yves

b) quand Yves va téléphoner. when Yves goes phone

'when Yves will phone.'

c) quand il va téléphoner.

d) *quand va téléphoner il.

e) *quand va-t-il téléphoner.

'when he will phone.'

An adequate account of the data presented above would have to provide answers to the following questions:

(i) Why is Subj $-V_{\text {fin }}+V_{\text {non-fin }}$ inversion possible in interrogatives with a strong subject but not in those with a weak subject (cf. (13a), (14a))?

(ii) What motivates the movement of both finite and non-finite verbal forms (resulting in Subj $-V_{\text {fin }}+V_{\text {non-fin }}$ inversion) in root and embedded interrogatives with strong subjects?

These questions will be addressed in the section below.

\subsubsection{STRONG AND WEAK SUBJECTS}

In his analysis of Italian interrogatives Rizzi (1991) suggests that pre-verbal subjects are assigned nominative Case under Spec-head agreement with the inflectional head of the highest functional projection in the IP-domain, whereas post-verbal sub- 
jects are assigned nominative Case by the inflectional head of a lower functional projection under government. ${ }^{15}$

Extending Rizzi's proposal to French and assuming that only strong subjects can occur in post-verbal position (Cardinaletti 1997), the contrast in grammaticality between (13a) and (14a) can be accounted for as follows. (14a) contains a weak subject, which should be assigned nominative Case under Spec-head agreement. With the moved participle intervening between the subject and the finite verb, the required configuration is destroyed. Since Case cannot be assigned, the Case Filter is violated, and ungrammaticality results. In (13a) the subject is strong and occurs in post-verbal position. As such, it is assigned nominative Case under government. Therefore the moved participle does not interfere with Case assignment, and the construction with Subj $-\mathrm{V}_{\mathrm{fin}}{ }^{+}$ $\mathrm{V}_{\text {non-fin }}$ inversion is well-formed. In this way, an answer to question (i) above is provided: the presence/absence of Subj $-V_{\text {fin }}+V_{\text {non-fin }}$ inversion in interrogatives with strong and in those with weak subject respectively is due to two different mechanisms of Case assignment associated with the two subject types.

\subsubsection{LICENSING SUBJECT - FINITE VERB + NON-FINITE VERB INVERSION}

In section 2.3 we argued that the trigger for (overt) I-to-C movement is a strong [+QUESTION] feature in $\mathrm{C}$. This feature is checked by the finite verb raising to $\mathrm{C}$. In the case of Subj $-V_{\text {fin }}+V_{\text {non-fin }}$ inversion both the finite and the non-finite verb forms move. Given that in the Minimalist system movement is driven by feature-checking requirements and that the feature-checking requirement imposed by the strong [+QUESTION] feature is satisfied by the finite verb raising to $\mathrm{C}$, the non-finite verb should not move unless there is another strong feature to be checked. This raises a few questions. What is this feature? Where is it located? Does Subj $-V_{\text {fin }}+V_{\text {non-fin }}$ involve head movement or some other type of movement?

It seems impossible to answer such questions with any certainty without a detailed analysis of constructions with Subj $-V_{\text {fin }}+V_{\text {non-fin }}$ inversion. However, this is beyond the scope of this paper. Therefore let us mention only the most recent research concerning the left periphery of Romance interrogatives (cf. Pollock 2001a, Pollock 2001b, Pollet-to\&Pollock 2002, among others). This research suggests that various aspects of the syntax of Romance questions derive from the highly split structure of the interrogative Romance CP field and the morphological properties of individual wh-elements which are responsible for the features they can check in the left periphery. Based on this, several types of interrogative constructions in Romance (e.g. subject clitic inversion, Subj $-V_{\text {fin }}+V_{\text {non-fin }}$ inversion, wh-in situ constructions) have been explained in terms of generalized remnant movement to the $\mathrm{CP}$ area. As we will see in the next section, the Subj $-V_{\text {fin }}+V_{\text {non-fin }}$ inversion occurs also in Slovenian, which shows that the

15 Assuming the Split-IP Hypothesis of Pollock (1989) and the relative order of projections of Belleti (1990), the two functional projections concerned are $\mathrm{Agr}($ eement) $\mathrm{P}$ (hrase) and T(ense) respectively. (Rizzi 1991: 17) 
phenomenon is not language-group-specific (Romance). How Subj $-V_{\text {fin }}+V_{\text {non-fin }}$ in Slovenian is to be analysed and whether or not the remnant movement analysis could be extended to Slovenian are matters we leave for future research.

\section{Verb movement in Slovenian interrogatives}

Slovenian belongs to the class of languages with overt interrogative wh-movement (Golden 1996a, 1996b; and Marvin 1997). Under Minimalist assumptions this means that the [+WH] feature of $\mathrm{C}$ in Slovenian is strong (as in English and French - cf. section 2 above). It must be checked overtly by the wh-phrase raising overtly to [Spec, $\mathrm{CP}$; if no movement occurs, ungrammaticality results (16a,b).

(16) a) Kaj posluša Marko?

what listens Marko

b) *Marko posluša kaj?

'What does Marko listen to?'

Slovenian shares another characteristic with English and French: as seen in (16a), the verb precedes the subject (Subj- $\mathrm{V}_{\text {fin }}$ inversion), which suggests overt I-to-C movement.

Let us now examine the properties of I-to-C movement in Slovenian interrogatives in more detail and compare them with those of I-to-C in English and French.

\subsection{Data III}

In Slovenian, auxiliaries as well as lexical verbs may undergo I-to-C raising (17a-b). In this respect Slovenian resembles French (cf. 4b, 6c), but differs from English, where only auxiliaries are allowed to raise (cf. 5a, c)).

(17) a) Kaj je Marko prinesel? what is-cl Marko brought

'What has Marko brought?'

b) Kaj bere Marko? what reads Marko

'What is Marko reading?'

I-to-C in Slovenian occurs in root (17) and in embedded interrogatives (18). This contrasts with English and French, where I-to-C is restricted to root clauses (cf. (5d), $(6 \mathrm{e}))$.

Povej mi

tell me

a) kaj je Marko prinesel.

what is-cl Marko brought

b) kaj bere Marko.

what reads Marko

'Tell me what has Marko brought/ is Marko reading.' 
I-to-C in English and French (in the case of interrogatives with a weak subject and Subj - $V_{\text {fin }}$ inversion) is obligatory. In contrast, Slovenian I-to-C is optional: cf. (17b) and $(18 \mathrm{~b})$, repeated below as $(19 \mathrm{a}, \mathrm{b})$, and their respective counterparts without Subj$V_{\text {fin }}$ inversion $(20 a, b)$, which are equally acceptable. ${ }^{16}$

(19) a) Kaj bere Marko? what reads Marko

'What is Marko reading?'

b) Povej mi, kaj bere Marko. tell me what reads Marko

'Tell me what Marko is reading.

(20) a) Kaj Marko bere? what Marko reads

'What is Marko reading?'

b) Povej mi, kaj Marko bere. tell me what Marko reads

'Tell me what Marko is reading.'

As in French interrogatives with strong subjects, both finite and non-finite verbal forms may raise across the subject (Subj $-V_{\text {fin }}+V_{\text {non-fin }}$ inversion) $-c f$. (13a), (15a,b) and $(21 \mathrm{a}, \mathrm{b})$. Note that in Slovenian, unlike in French, Subj $-\mathrm{V}_{\text {fin }}+\mathrm{V}_{\text {non-fin }}$ inversion is optional both in root and in embedded clauses (cf. the well-formed (17a), (18a), where only the finite verb has raised.)

(21) a) Kaj je prinesel Marko? what is-cl brought Marko

'What has Marko brought?'

b) Povej mi, kaj je prinesel Marko. tell me what is-cl brought Marko

'Tell me what Marko has brought.'

\subsection{Asymmetric and symmetric I-to-C}

In English and French, I-to-C movement shows a clear asymmetry between root and embedded interrogatives. As argued in section 2.3, this asymmetry is due to the presence/absence of the [+QUESTION] feature of the root and embedded $\mathrm{C}$ respectively. In Slovenian, however, the root/embedded distinction is weakened; I-to-C can optionally apply in embedded interrogatives. Furthermore, in some Romance languages (Spanish, Catalan, Romanian ${ }^{17}$ ), this distinction disappears altogether; I-to-C is obligatory in both

16 The Subject-Clitic Auxiliary inversion (as in (17a, 18a)) is obligatory (cf. *Kaj Marko je prinesel./*Povej $m i$, kaj Marko je prinesel.), which, however, can be attributed to the second-position (2P) constraint on clitic placement in Slovenian.

17

Cf., for instance, Rizzi (1991). 
root and embedded contexts. If, as we claimed (2.3), the embedded C lacks the [+QUESTION] feature and hence I-to- $\mathrm{C}$ is not induced, then what forces I-to- $\mathrm{C}$ in languages with no root/embedded asymmetry? We would like to propose that I-to-C in embedded interrogatives is triggered by a "finiteness" feature, [+FIN]. This feature is present on the clausal head $\mathrm{C}$ of every type of finite clause and in order for it to be checked, the finite verb must raise from I to $\mathrm{C}$, either overtly or covertly, depending on the strength of the [+FIN] feature of $\mathrm{C}$. On these assumptions, the interrogative $\mathrm{C}$, both in languages with asymmetric and in those with symmetric I-to-C, would have the feature specification as shown in (22).

$$
\begin{array}{ll}
\mathrm{CP}_{\text {interrogative/root: }}: & {[+\mathrm{WH}]} \\
& {[+\mathrm{QUESTION}]} \\
& {[+\mathrm{FIN}]} \\
\mathrm{CP}_{\text {interrogative/embedded: }}: & {[+\mathrm{WH}]} \\
& {[+\mathrm{FIN}]}
\end{array}
$$

In languages of the English/French type, exhibiting asymmetric I-to-C, the [+QUESTION] feature of root $C$ is strong, forcing overt verb raising to $C$. The [+FIN] feature is weak, hence checked covertly, with the verb in embedded interrogatives staying in I in the overt syntax. On the other hand, in Spanish-type languages, with symmetric I-to$\mathrm{C}$, both the [+QUESTION] and the [+FIN] features are strong, triggering overt I-to-C in root as well as in embedded interrogatives.

The above proposal, based on the Minimalist checking theory of movement, provides a uniform account of obligatory asymmetric and symmetric I-to-C. However, it is problematic for languages, such as Slovenian, in which I-to-C is optional.

\subsection{Optional I-to-C}

The optionality of movement poses a problem to the Minimalist analysis as proposed by Chomsky (1995). Minimalism postulates only two types of formal features in terms of strength: strong features and weak features. Strong features, being visible at PF, must be checked overtly (before Spell-Out). Weak features, being invisible at PF, can and must (by the principle Procrastinate) be checked covertly (after Spell-Out). Consequently, there is no optional movement, be it overt or covert.

A possible solution to the problem of optionality can be found in Collins (1997). He suggests that weak features be defined as those features which "[...] may be checked only by pure features" (op.cit.: 117), where a pure feature is "[...] a feature that is not part of any lexical item[...]" (ibid.) ${ }^{18}$, and proposes the following definitions of strong and weak features respectively:

18 Given this definition of weak features and Chomsky's (1995) proposal that a feature may move away from its lexical item only covertly, "[...] it follows directly that weak features will be checked only by covert movement". (Collins 1997: 117). 
(23) a) strong feature: a feature that is visible at PF

b) weak feature: a feature that may be checked only by a pure feature

(Collins 1997:117; (4a,b))

Since, as pointed out by Collins (op.cit.: 118), these two definitions are independent, they can be cross-classified, allowing for a third type of feature: a feature that is neither strong nor weak. Such a feature would not be visible at PF and would not have to be checked by a pure feature. As a result it could be checked either overtly or covertly, ${ }_{19}$ hence movement could be optional.

Applying the modified theory of features as proposed by Collins to verb movement in Slovenian interrogatives, the optionality of Slovenian I-to-C in root and embedded interrogatives can be straightforwardly accounted for in the following way: in Slovenian the features [+QUESTION] and [+FIN] are neither strong nor weak and may therefore be checked either by overt or by covert I-to-C.

To conclude, adopting the core idea of the Minimalist Program that cross-linguistic variation in the surface order of clausal constituents is the result of parametric variation in feature strength of functional heads, and a theory of features which postulates three types of features, allows for a uniform account of both obligatory (asymmetric and symmetric) as well as optional I-to-C in interrogatives. Specifically, assuming the relevant features of the clausal head $\mathrm{C}$ to be [+QUESTION] and [+FIN], the typological differences in interrogative $\mathrm{I}$-to-C in the languages under consideration can be ac-counted for in terms of different feature values (strong/weak/neither strong nor weak) - cf. (24).

(24) C:

[+ QUESTION]
STRONG
STRONG
NEITHER STRONG
NOR WEAK

[+FIN]
WEAK
STRONG
NEITHER STRONG
NOR WEAK

Type of (overt) I-to-C

$\begin{array}{ll}\begin{array}{l}\text { OBLIGATORY } \\ \text { (English/French) }\end{array} & \text { ASYMMETRIC } \\ \text { OBLIGATORY } & \text { SYMMETRIC } \\ \begin{array}{l}\text { (Spanish) } \\ \text { OPTIONAL } \\ \text { (Slovenian) }\end{array} & \text { SYMMETRIC } \\ \end{array}$

\section{Conclusion}

In this paper we have examined verb movement in wh-interrogatives in English, French and Slovenian against the background of recent approaches to this phenomenon within the framework of Chomskyan generative grammar. We have argued that Ito- $\mathrm{C}$ verb movement in interrogatives occurs independently of wh-movement and have identified the [+QUESTION] feature of root $\mathrm{C}$, denoting interrogative illocutionary force,

19

Note that no Procrastinate condition is assumed here (cf. op.cit.: 117-18). Collins argues that economy conditions are local (in the sense that they are evaluated at each step of derivation) rather than global (evaluated by comparing whole derivations). He eliminates global economy conditions, such as Procrastinate, and reduces economy conditions to only two conditions, both of them local: Last Resort and Minimality (cf. op.cit: 9). 
as the licenser of I-to-C raising in root interrogatives. Adopting the Minimalist checking theory of movement (Chomsky 1995), modified as in Collins (1997), we have proposed an account of the typological differences in I-to-C (overt/covert, asymmetric/ symmetric, obligatory/optional) in terms of the featural content of the functional head $\mathrm{C}$ and the strength of the relevant features [+QUESTION] and [+FIN].

\section{References}

BeLletTI, Adriana (1990). Generalized Verb Movement: Aspects of Verb Syntax. Turin: Rosenberg and Sellier. CARDINALETH, Anna (1997). 'Subjects and clause structure.' in: Lilliane Haegeman (ed.) Element of Grammar. Handbook of Generative Syntax. Dordrecht: Kluwer Academic Publishers.

CHomsкy, Noam (1995). The Minimalist Program. Cambridge, Massachusetts: The MIT Press.

CHUNG, Sandra (1982). 'Unbounded Dependencies in Chamorro Grammar' Linguistic Inquiry 13: 39-78.

Collins, Chris (1997). Local Economy. Linguistic Inquiry Monograph 29. Cambridge, Massachusetts: The MIT Press.

Golden, Marija (1996a). 'Interrogative Wh-Movement in Slovenian and English.' Acta Analytica 14: 145-187.

GoLdEN, Marija (1996b). 'K-premik in skladenjski otoki v slovenski skladnji.' Razprave XV: 237-253.

HAEGEMAN, Liliane (ed.) (1997). Elements of Grammar. Handbook of Generative Grammar. Dordrecht: Kluwer Academic Publishers.

ILC, Gašper (2002). Glagolski premik in funkcijske zveze v tvorbeni slovnici. MA thesis. Ljubljana: Filozofska fakulteta.

LASNIK, Howard (1999). Minimalist Analysis. Oxford: Blackwell Publishers.

LightFOOT, David \& Norbert HoRnstern (eds.) (1995). Verb Movement. Cambridge: University Press.

MARVIN, Tatjana (1997). Wh-movement in the generative theory with special reference to Slovenian. BA thesis. Ljubljana: Filozofska fakulteta

Poletto, Cecilia \& Jean-Yves Pollock (2002). 'On the Left Periphery of Romance Interrogatives. Glow Newsletter 48: 47-48.

Pollock, Jean-Yves (1989). 'Verb Movement, Universal Grammar and the Structure of IP.' Linguistic Inquiry 20: $365-424$

PoLlock, Jean-Yves (2001a). 'On the Left Periphery of Some Romance Wh-Questions.' Handout, University of Leipzig, February 2001.

Pollock, Jean-Yves (2001b). 'Subject clitics, Subject Clitic Inversion and Complex Inversion: Generalizing Remnant Movement to the Comp Area.' Handout, University of Leipzig, February 2001.

QUIRK, Randolph et al. (1999). A Comprehensive Grammar of the English Language. 15th edition. Longman.

RızzI, Luigi (1997). 'The Fine Structure of the Left Periphery.' in: Lilliane Haegeman (ed.) Elements of Grammar. Handbook of Generative Syntax. Dordrecht: Kluwer Academic Publishers.

ROHRBACHER, Bernhard Wolfgang (1999). Morphology-Driven Syntax. A theory of V to I raising and pro-drop. Linguistik Aktuell. Amsterdam / Philadelphia: John Benjamins Publishing Company.

\section{Povzetek}

\section{GLAGOLSKI PREMIK IN VPRAŠALNI STAVKI}

$\mathrm{V}$ prispevku obravnavamo glagolski premik v dopolnjevalnih vprašanjih z vidika novejših pristopov $\mathbf{k}$ medjezikovni raznolikosti površinskega reda stavčnih sestavnikov $\mathrm{v}$ okviru čomskijanske tvorbene slovnice. Osredinjamo se na premik glagola iz jedra $\mathrm{P}($ regib) $\mathrm{v}$ hierarhično višje jedro $\mathrm{V}$ (ezalo) - t.i. P-v-V premik. Na podlagi primerjave tovrstnega premika $\mathrm{v}$ angleščini, francoščini in slovenščini ugotavljamo tipološke značilnosti P-v-V premika v omenjenih jezikih glede na: (i) vrsto vprašalnega stavka, v katerem se pojavlja (samo v glavnem (asimetrični P-v-V)/v glavnem in odvisnem (simetrični P-v-V)); (ii) njegovo (ne)izraženost $\vee$ glasovni verigi (slišni/neslišni P-v-V); (iii) (ne)obveznost (obvezni/poljubni P-v-V). Predlagamo enotno razčlembo P-v-V premika v primerjanih jezikih, ki temelji na modificirani inačici minimalistične teorije obeležij Noama Chomskega (Chomsky 1995). 